\title{
بناء العتبات النصيّة في الرحلة الأدبية الحديثة
}

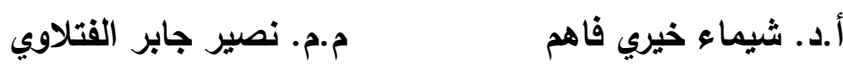 \\ جامعة القادية/ كلية الآداب
}

يحاول هذا البحث إستقراء البناء في العتبات النصية للرحلة الأدبية منمثلة في العنوانات الرئيسة

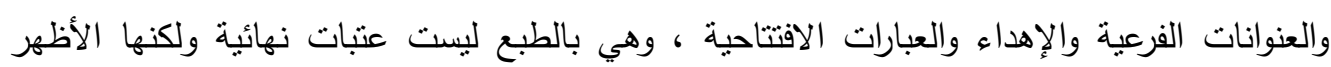

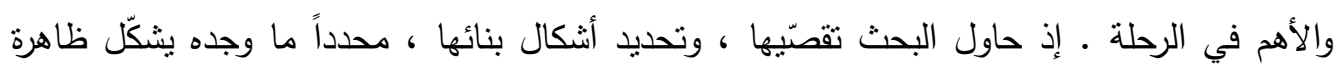

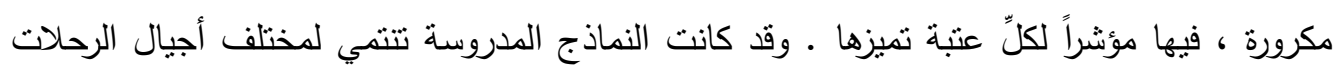

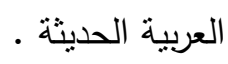




\section{Abstract}

Building the textual thresholds in the modern literary journey--

The first research investigates the construction in the literally entries of the modern literature tour represented in, primary subjects, secondary subjects , inscription and introductory expressions . These entries are the most important than the others, that the research try to study the types of its construction and point to the frequent types in them, so the studied types belong to different generations of the modern Arabic researches.

المبحث الأول : العنوانات الرئيسة :

هي عتباتُ بنائية مكثفةُ دالّة على محتوى المتن، وَمن محدّدات صُنع المعنى عندَ إكتمال

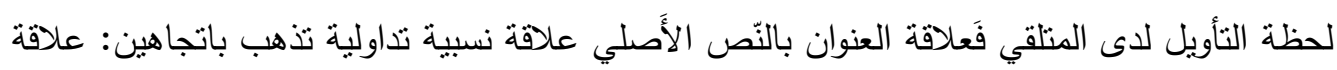

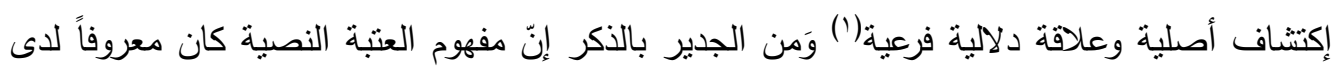

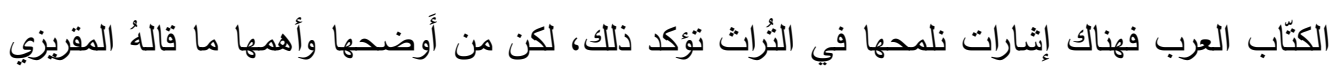

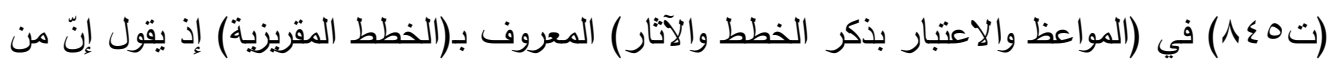

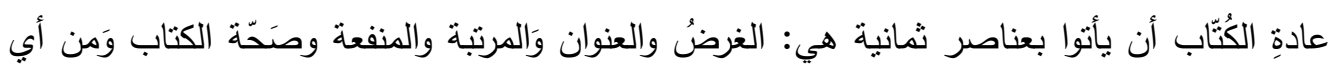
صناعة هو وكم فيه من أجزاء وأي أنحاء التعاليم المستعملة فيه(؟). والعنوان منطقة تأويلية ومفتاحاً

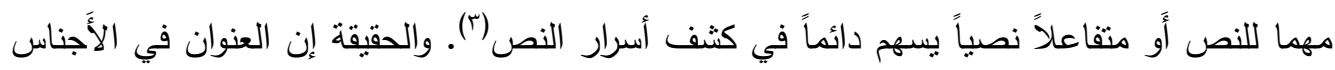

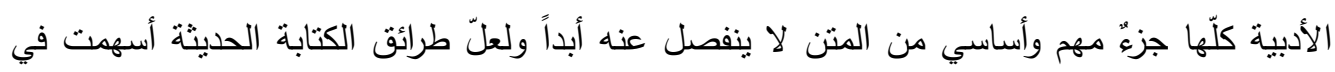
ذللك كثبراً حيث يَتصدر العنوان مقدمة كلّ عمل بصورةٍ لافتةٍ للنظر والتأويل، وفي الرحلة الأدبية

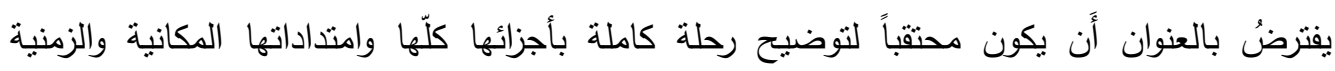

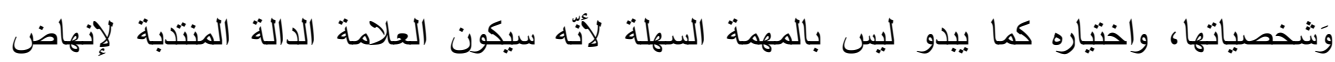
((الرحلة)) من بين كم العنوانات الرَحليّة. 
إنّ العنبات النّصية التي سلطت عليها الأضضواء النقَية بوصفها مواقعاً (ستراتيجية) في النصأ)،

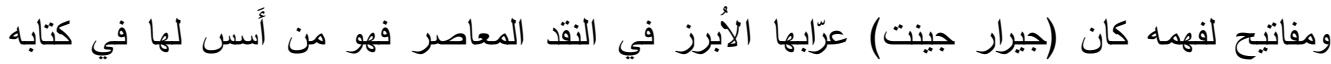

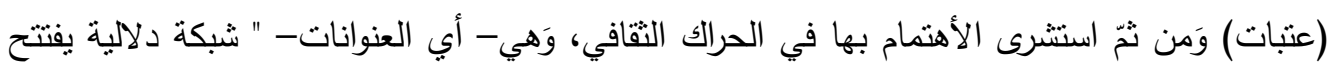

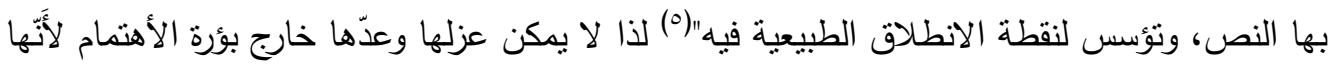

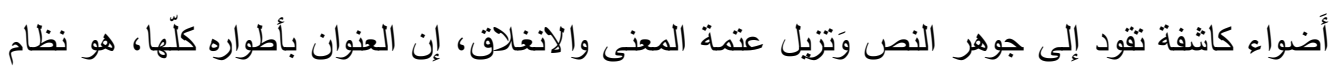

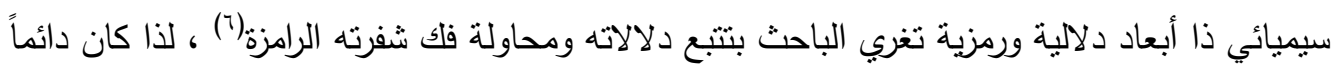

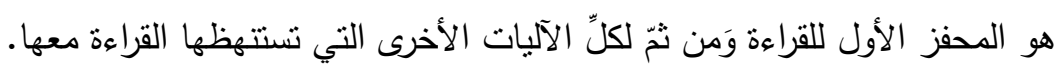

\section{أولاً : العنوان السجعي التقليدي : 20 - أن}

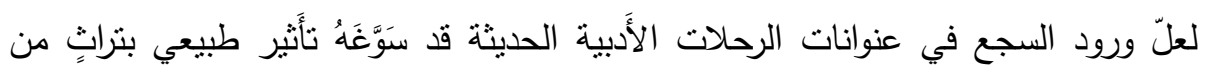

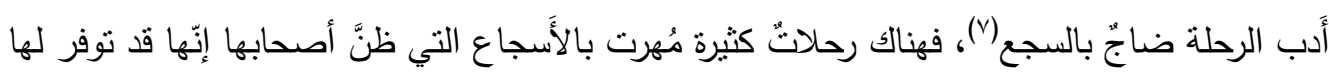

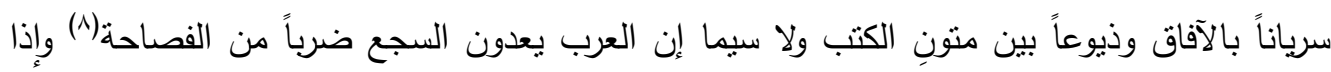

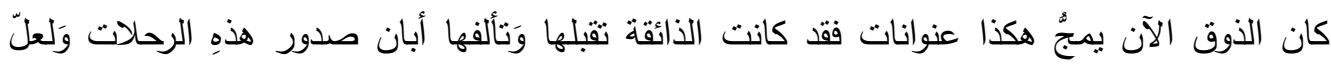

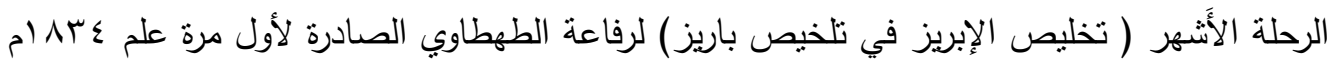

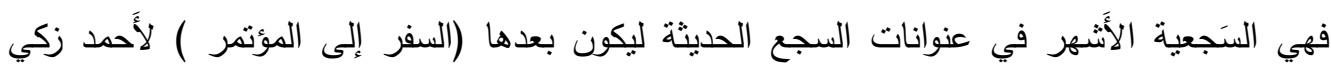

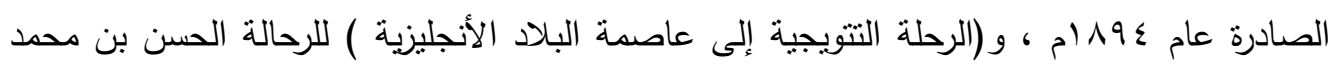

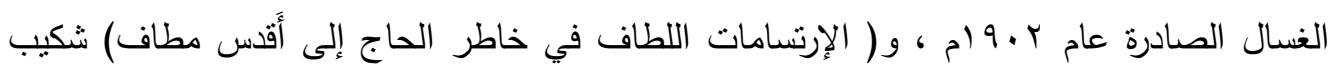

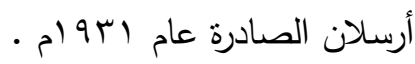

وَلعل المنلقي المعاصر سيجدُ أنّ هذِه العنوانات لم يعد لها إنشتباكُّ مع النص، وَ يمكننا أَن نخلص إلىى نتيجة نحددها في الآتي :

1-العنوان السجعي بدأ ينحسر عن الرحلة الأَدبية المعاصرة بعد أَن كان سائداً فيها لأسباب تأَريخية

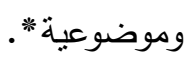

r-العنوان السجعي جزءٌ منفصل عن الرحلة وهو لا يشكّل جزءاً من البناء بقدر ما يشكل جزءاً من

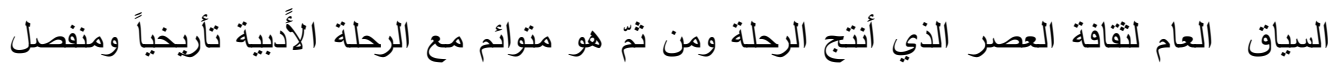
عنها لو حاكمناها بتلقٍ راهن. 
ب-العنوان السجعي محاولة للتمايز والتغاير فيما لو أستعل اليوم لإنقطاع الثقافة الراهنة مع السابقة

بسبب إختلاف الزمان وَتطور الحياة الثقافية بمناهجها كلّها.

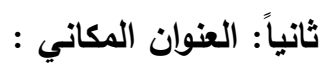

وهو عنوان يلجأ إلى ذكر اسم مكان الرحلة بصورة واضحة ليوحي للقارئ إنّهُ أَمام رحلة

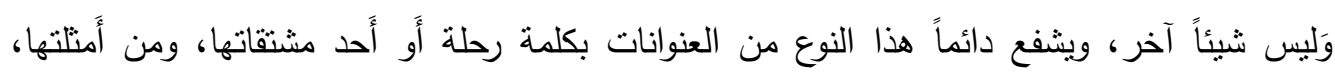

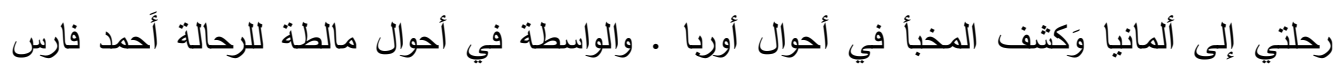

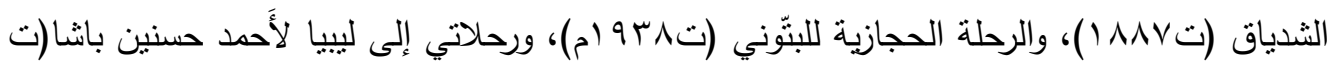

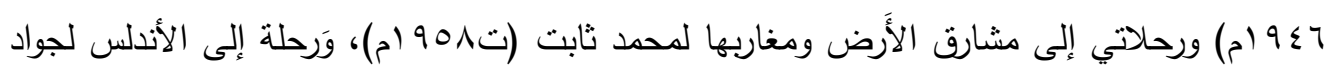

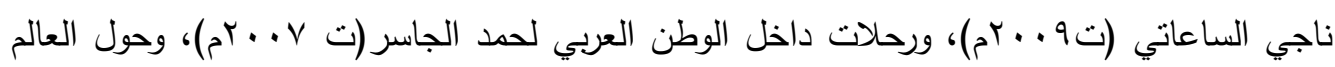

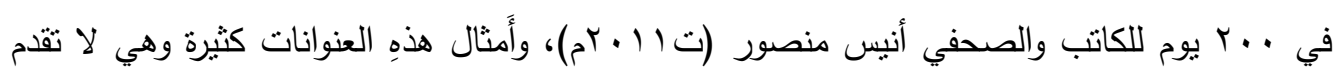

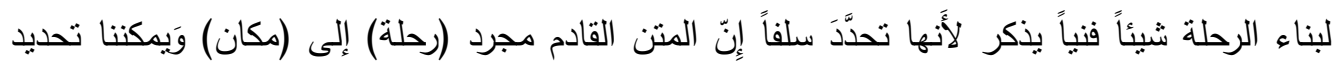

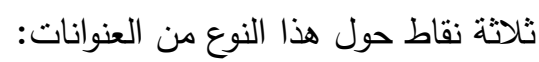

ا-إنّ هذا النوع من العنوانات لا يقدم شيئاً للقارئ، وُلا للرحلة على المستوى البنائي، لأنة مجرد توضيح لماهية المتن وإنشارة إلى نوعه.

ץ-العنوان البسيط، الواضح، المحُدَّد لا بسهم في مدّ أَواصر التأويل مع متن الرحلة الذي يبقى في

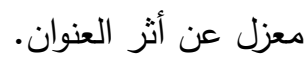

ب-العنوان حينما يركز على الثقرير والثرح لا يبقى منه في ذهن المتلقي غير الأَثر الإخباري لأنة خال من الفنية والأدبية.

ومَن تأمل مجموعة كبيرة من هذهِ العنوانات نجدها لا تختلف عن بعضها إلا باسم المؤلف فكلهاُ نكرر الجملة المفيدة نفسها: رحلة إلى جزر مالديف، لمحمد لناصر العبودي. الرحلة إلى أمريكا للرحالة: محمد لبيب البتّانوني. 
الرحلة النجدية الحجازية للشيخ، محدد بهجة البيطار .

رحلة إلى الدغرب العربي، أحمد حسين شرف الدين.

رحلتي إلى اليمن العربية السعيد، أحمد فريد رفاعي.

رحلة الحج إلى بيت الله الحرام، محمد الأمين الثنقطِي الجنكي.

نَحَظ إنّه مجرد تكرار مُنقطع لغوياً عن عالم الرحلة لا يميزها فنباً ولا يقدم لها غير التوثيق، لأن

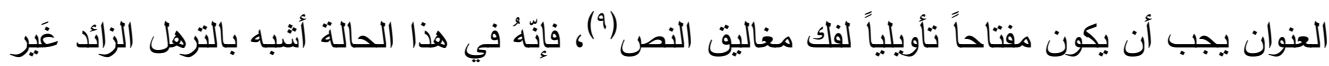

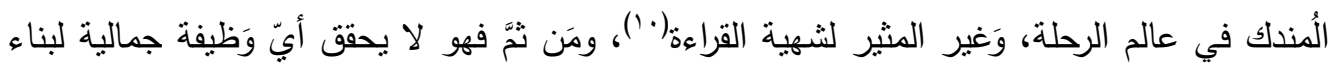

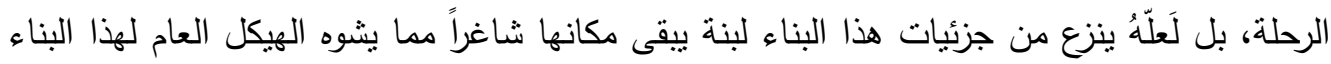

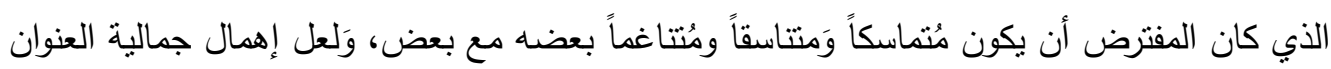

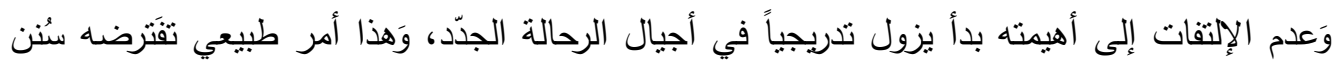

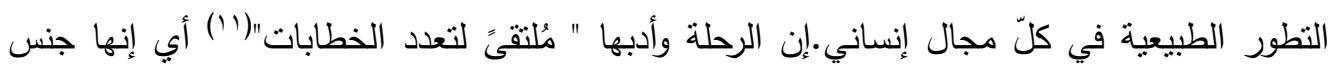

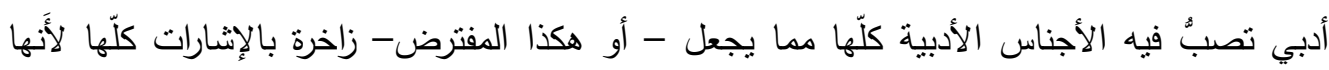

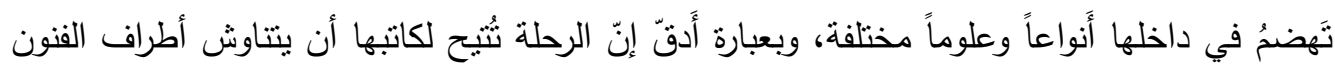

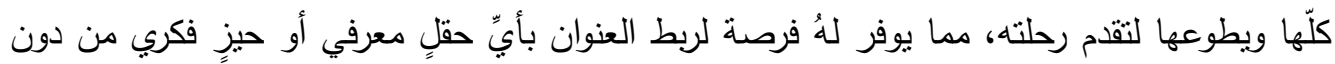

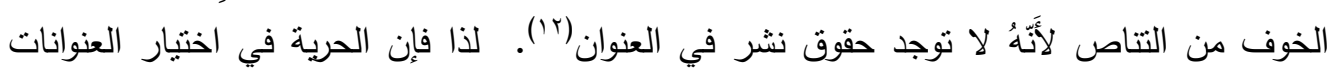

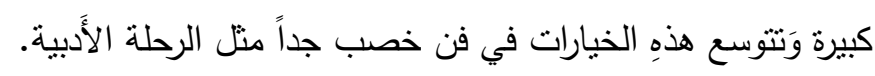
ثالثاً : العنوان القني المركب:

وهو العنوان المتضمن تركيباً لغوياً دالاً بمكن أَنْ نتزاح دلالاته مع تغيرات وتأويلات مختلفة

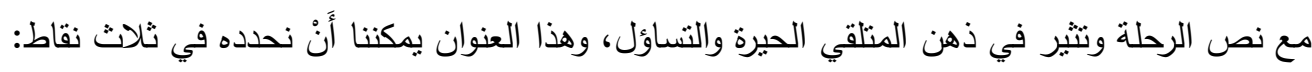
ا-هو عنوان فني يلجأ إلى اللغة وما توفره من جناسات وكنايات ومجازات، أو قد يقطع جزءاً من فكرة

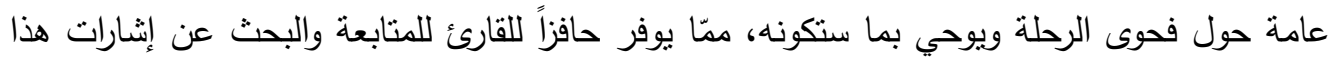
العنوان داخل الرحلة. 


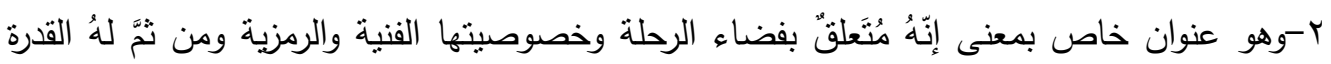
على تلخيص معنىً شامل في اختزالٍ دال.

ب-العنوان الفني المُركب كما أسميناه نرى إنَّهُ أَعلق بالرحلةِ من باقي الأَجناس السردية لأَنَّه يصف

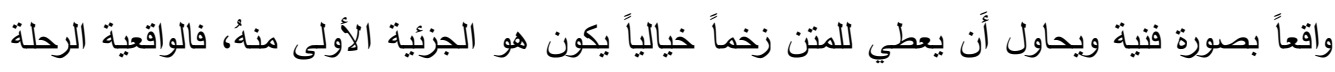

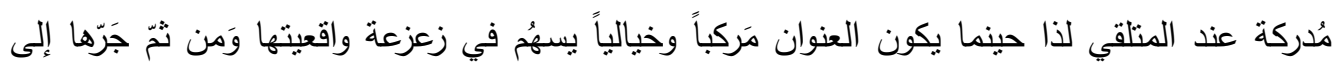
ساحة الخيال الذي بريده الُمتلقي دائماً.

فَعنوانات منل (درب الثوك) لدكتور سامي الدهان وَ(تذكار الصبا) لهحمد لطفي جمعة، وَ(الدنيا في

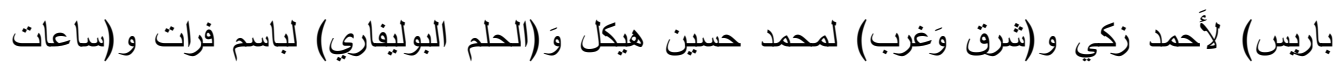

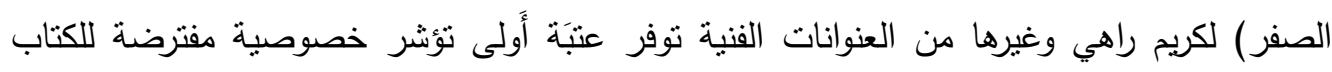

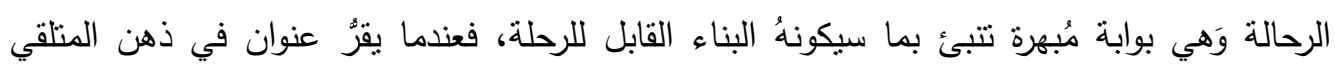

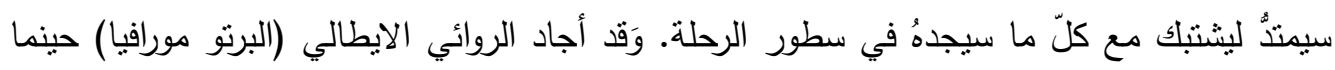

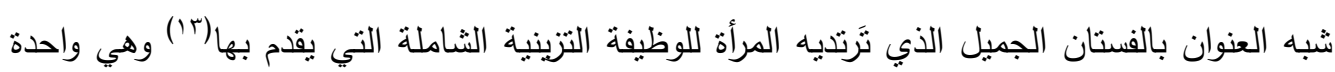
من وظائف أخرى للعنوان(؛) (1).

إنّ العنوان أهم منيرات القراءة فهو المواجهة الأولى مع القارئ وأول رسائل النص إليه. فكلّما كان

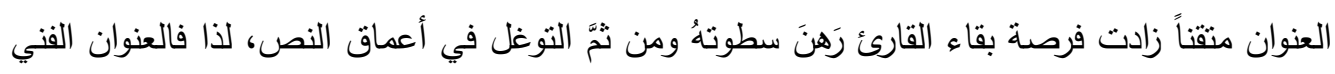

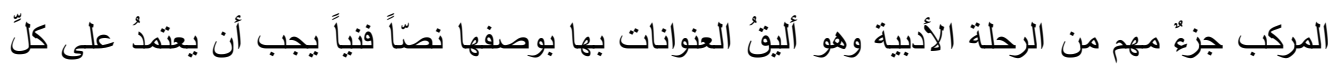

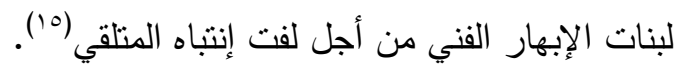

المبحث الثاني: العتبات النصيّة الأخرى :

أولاً : العنوانات الفرعية: - n

حينما يكتمل العنوان الرئيس في ذهن الرحالة وَتنتقرُ صيغتهُ يضيف عليه أحياناً عبارات

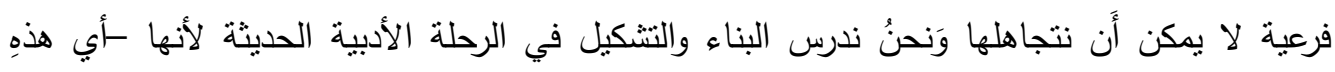

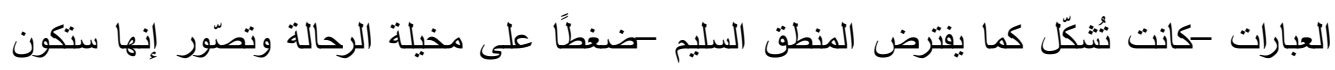

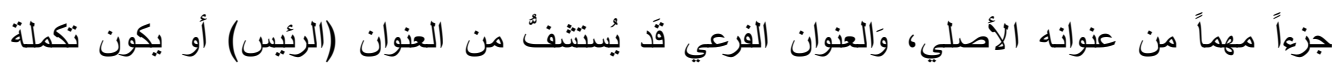


للمعنى، ويسميه بعض الدارسين بالعنوان الثاني أَو الثانوي(1) وهو لا يخرج عندنا عن التقسيرات الآتية:

1-هو عنوان ثانٍ يكثفُ العنوان الأَول وَيعطيه تأكيداً وزخماً.

ץ-هو عبارة عن شرح إفهامي يتصوّر الرحالة إنَّ عنوانه الرئيس به حاجه إليه.

r-هو عبارة تخصصية تَحصرُ العنوان في جنس الرحلة الأدبية وتخرجهُ عن الفنون الأدبية الأخرى.

إنّ كلَّ إثشارة إفاهمية من الرحالة تُبئُ عن مسارٍ للفهم يَفتترضَهُ (المُشير) سَيسلكه (المُشار إليه) ولكن

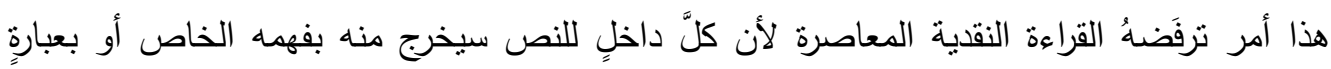

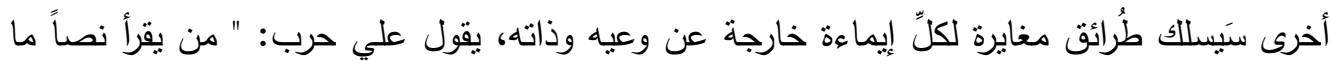

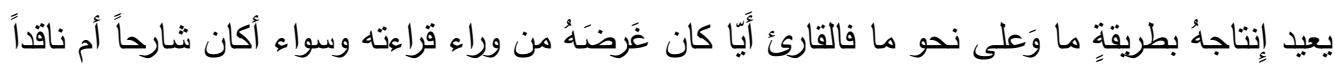

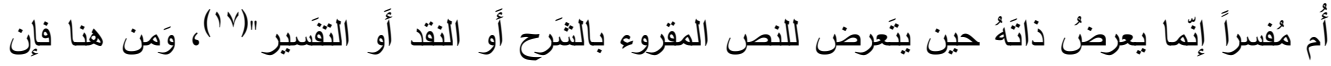

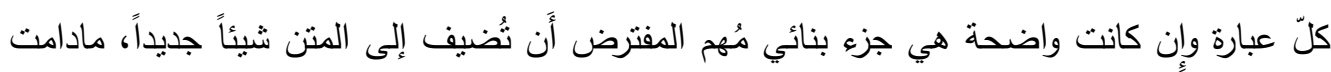

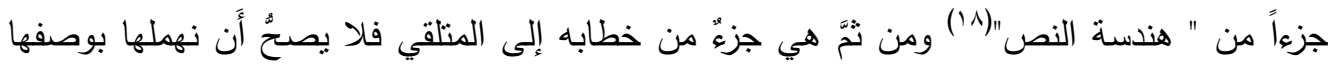

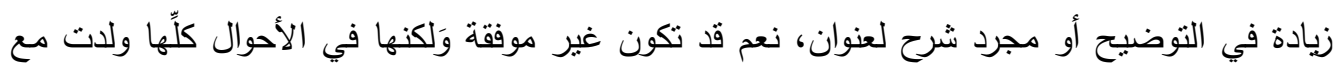

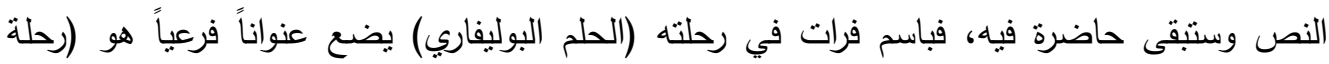
كولومبيا الكبرى) وهذهِ الجملة نلحظ إنها خصصت فئن فئ (الحلم البوليفاري) هو رحلة... وإلى كولمبيا وهي رحلةُ كبرى.

ونلاحظ إن الكاتب أنتّ ما بدأه في العنوان ليخلق الابهار المطلوب لجذب إنتباه القارئ، حقق العنوان

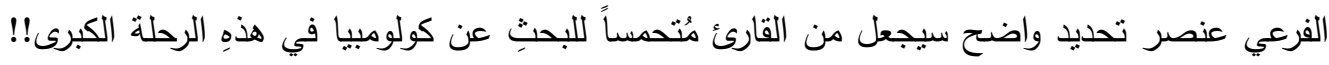

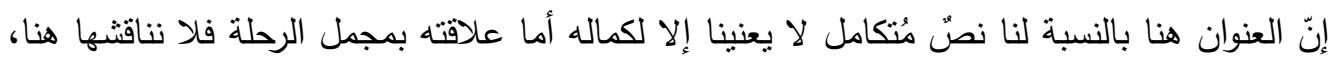
ويضيف الرحالة (محمد العبودي) في رحلته (من روسيا البيضاء إلى روسيا الحمراء) عنواناً فرعياً

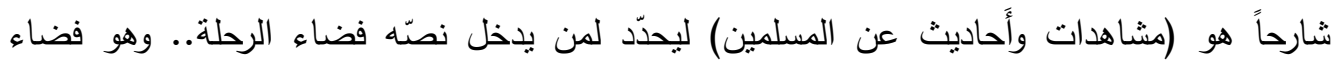

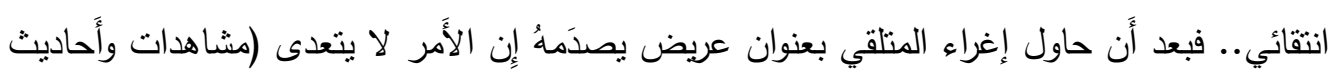

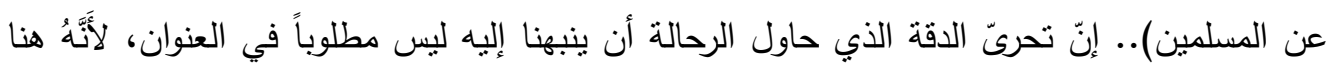

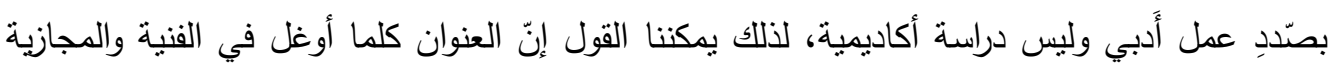




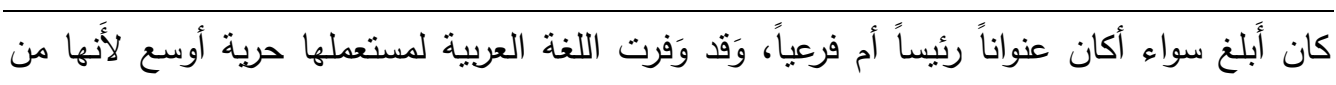

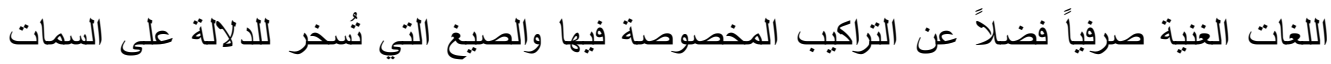

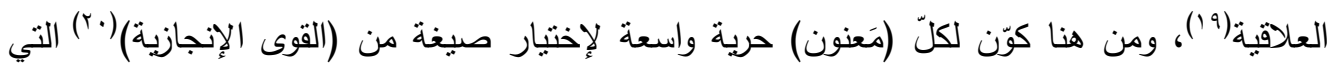

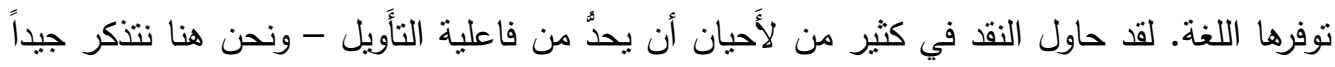

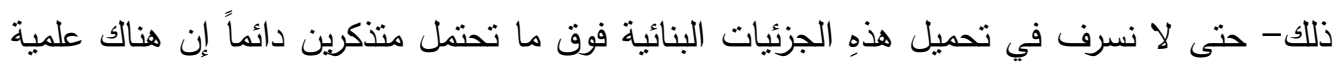

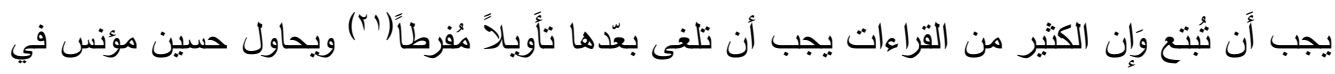

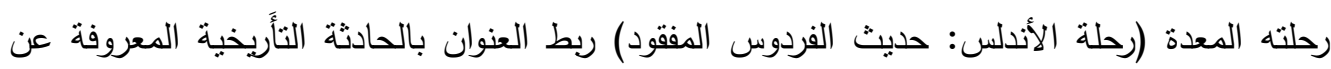

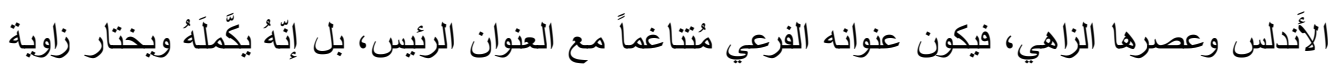

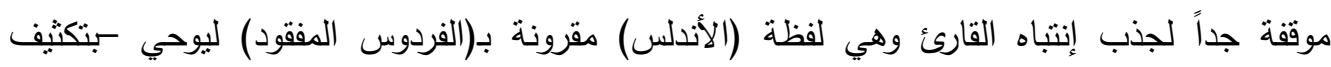

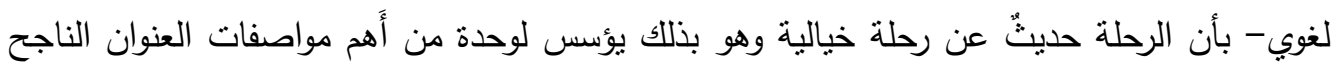

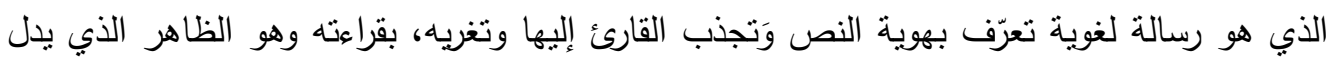

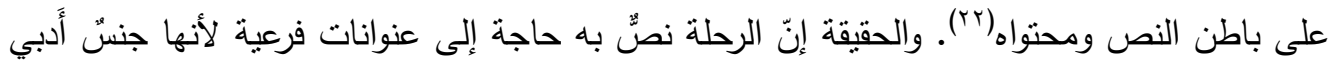

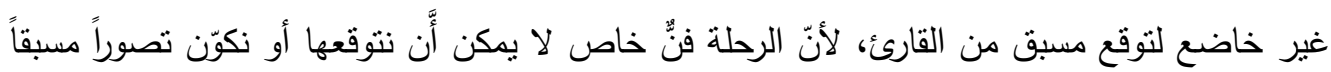

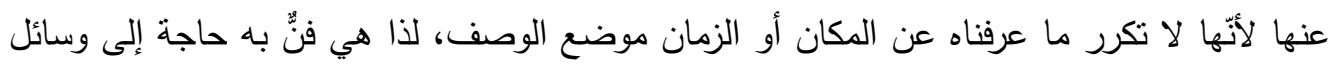

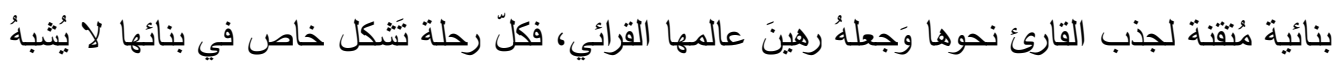

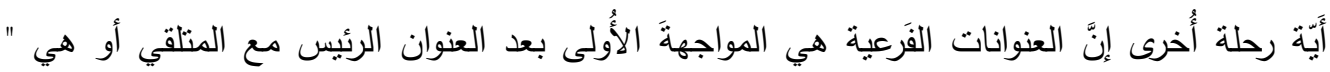

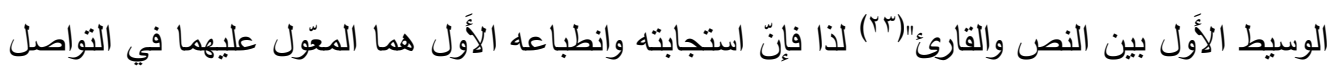

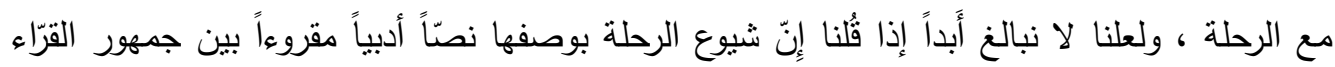

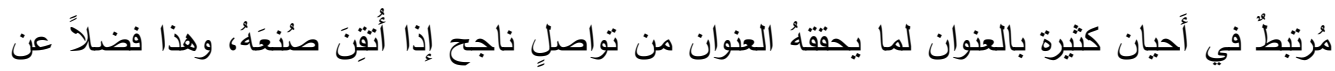
متن الرحلة ورصانتها واسم كاتبها والحقيقة إنّ تلك المؤشرات الخارجية أي (العنوان الأصلي الفرعي بوني

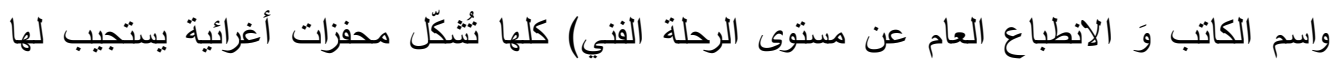

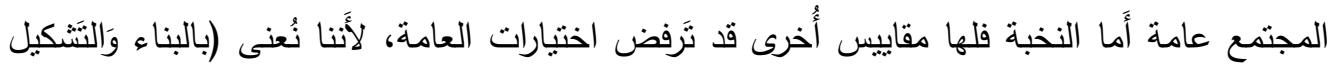

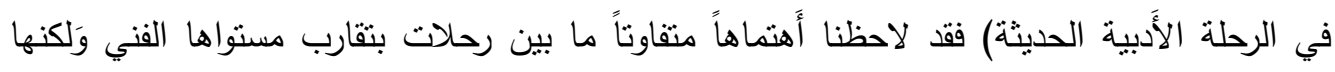

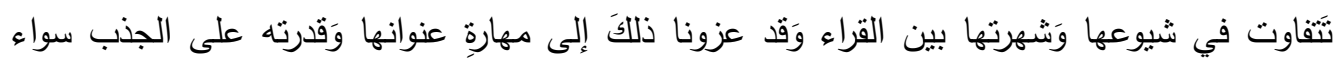

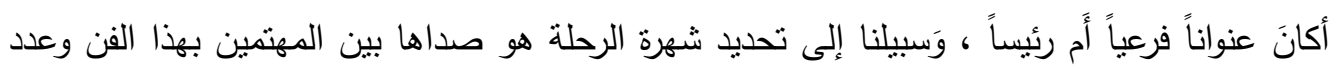

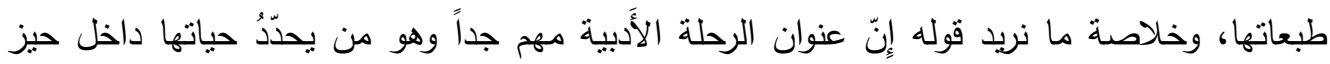

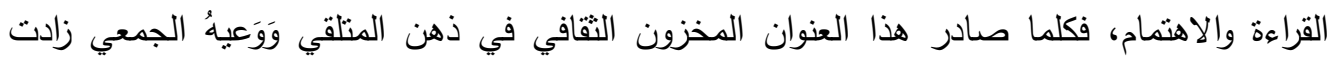


العـــــــد التاسع والعشرون

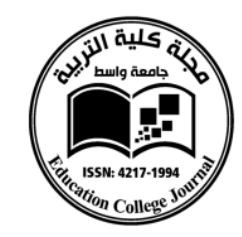

فرص بقاء الرحلة محاوراً فاعلاً في الراهن الثقافي لأَن الرحلة الأدبية كثيراً ما تكون استكثافاً لفهم

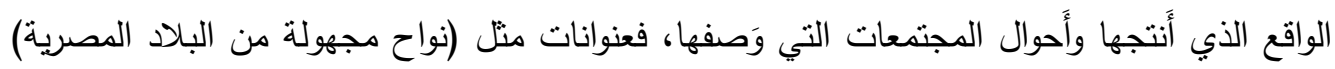

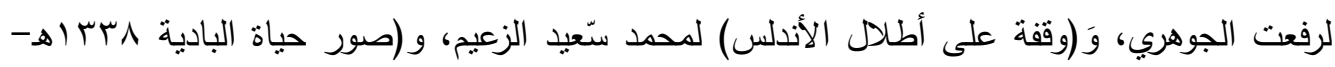

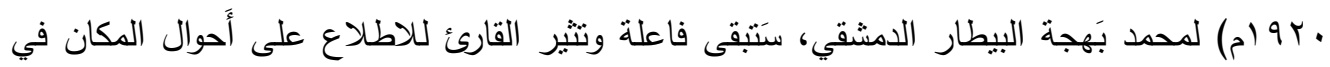

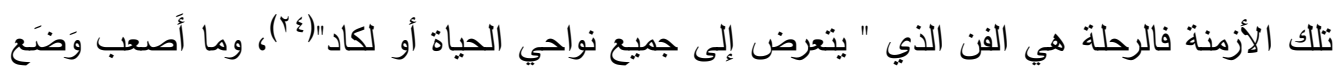

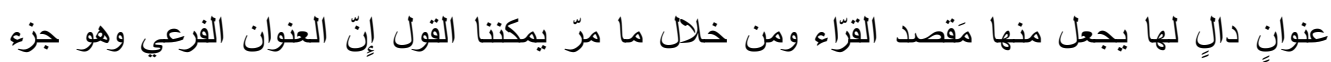

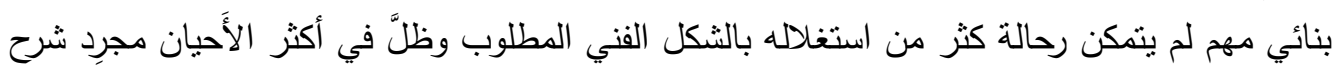

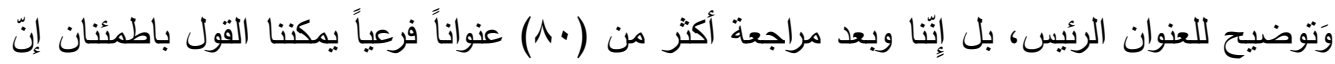

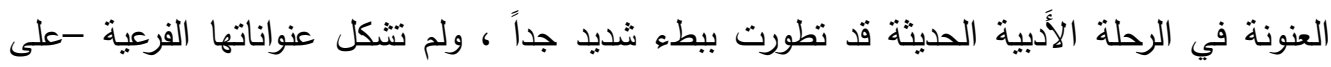

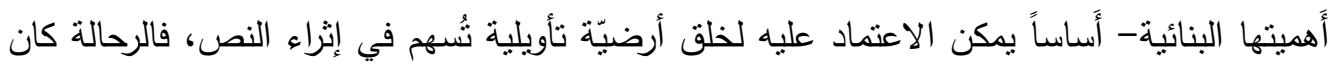

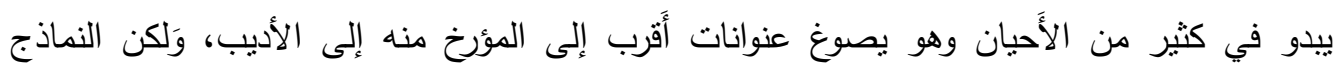

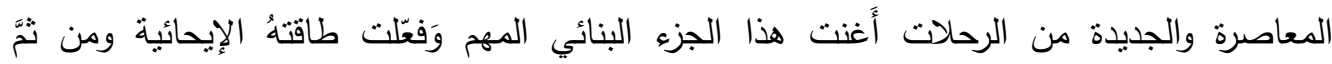

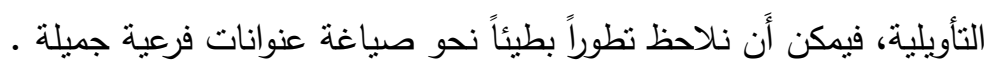

\begin{tabular}{|c|c|c|c|c|}
\hline نوع العنوان & سنة الطبع & اسم الرحالة & العنوان الفرعي للرحلة & $ت$ \\
\hline سجع & & رفاعة الطهطاوي & الايوان النفيس بإيوان باريس & 1 \\
\hline خبر بسيط & مام & أَحمد زكي & أَيامي الثُلاثة في المؤتمر & r \\
\hline خبر بسيط & . & محمد بهجة & صور من حياة البادية & $r$ \\
\hline خبر بسيط & (9Y1 & أَحمد شفيق & 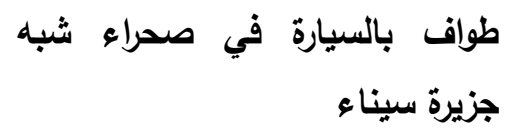 & $\varepsilon$ \\
\hline سجع & lark & عباس & الزهور في رامبور & $\bullet$ \\
\hline خبر بسيط & إ) & زكي مبارك & بين الهوى لما في مدينة النور من صراعل والهلدى والضلال & 7 \\
\hline سجع & r & شكيب ارسلان & الحاج اللى أَقَس مطاف اللطاف في خاطر & $v$ \\
\hline
\end{tabular}




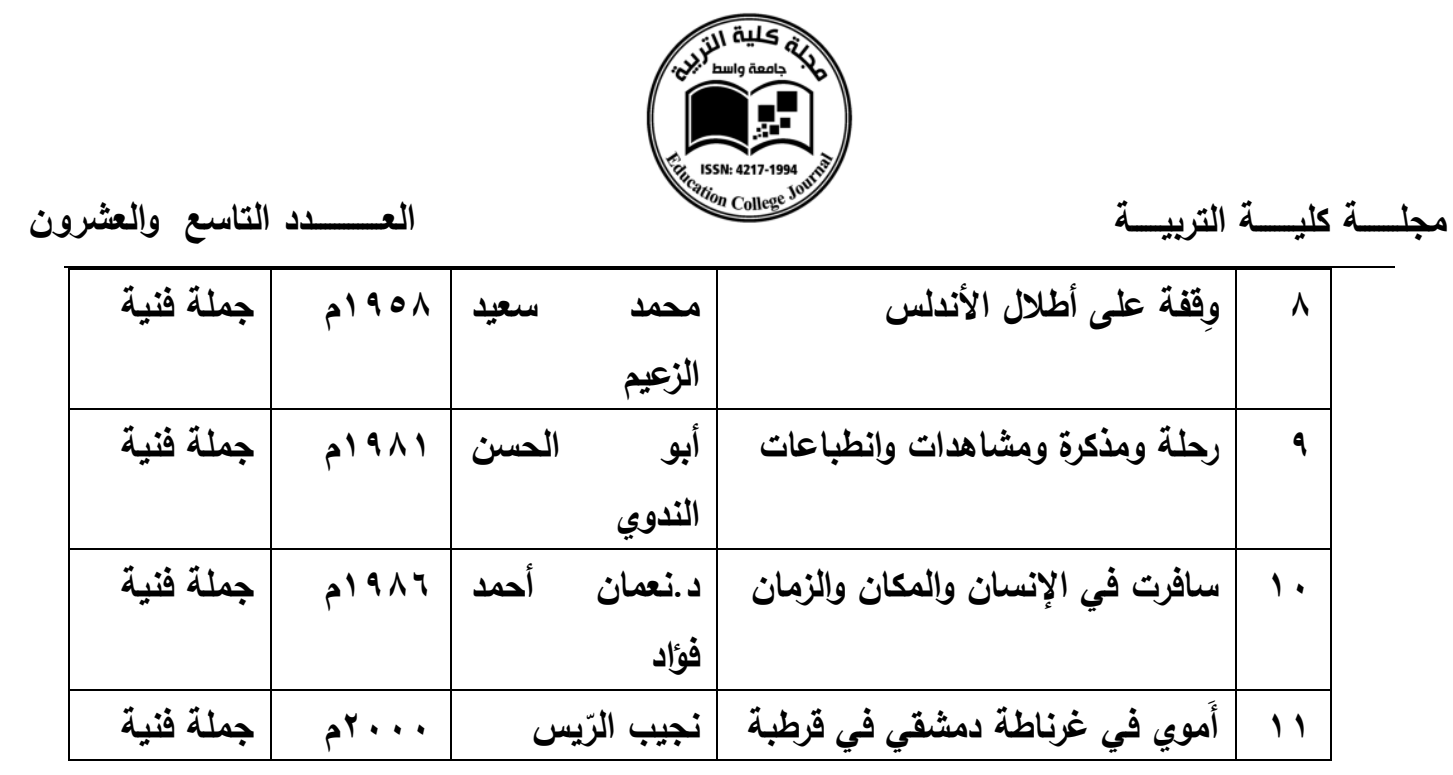

إنّ كلّ عنبة بنائية مهما كانت دَقيقة تُشهم في ترصين الهيكل العام للبناء لذا فإن العنوانات الفَرعية أَّ

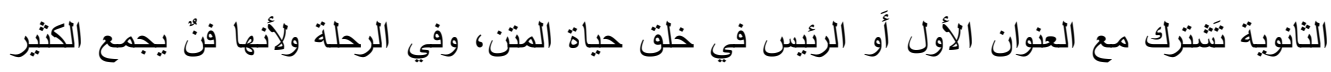

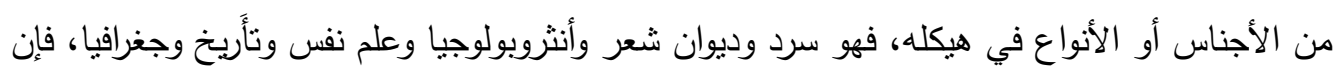
كلّ جزئية تعطي لهذا البناء مقبولية ومصداقية الواعية عند الآخر القارئ أَو الناقد.

ثانياً: الإهداء :

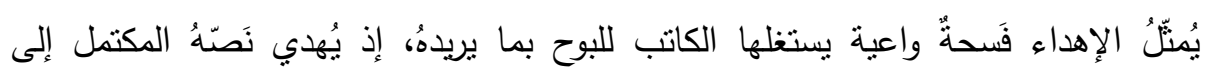

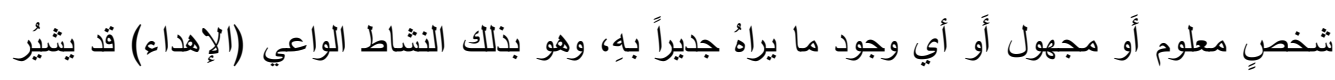

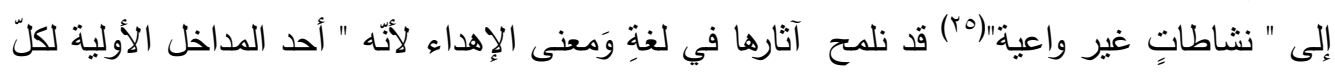

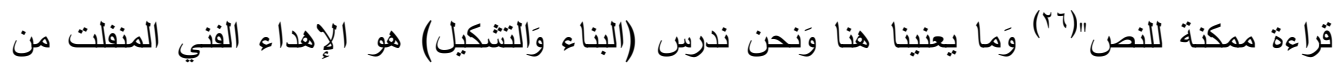

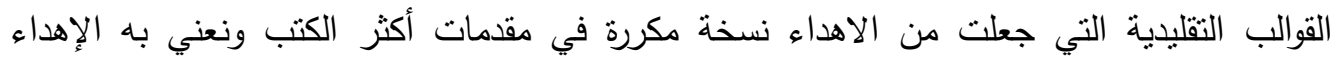

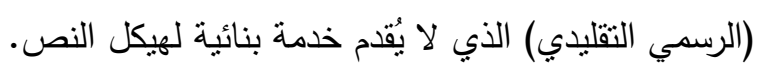

إنّ الإهداء هو الرسالةُ الثانية التي تواجه القارئ بعد العنوان ولأنَّه نص مُختزل وَمكثق فإنّه لا بد أَنْ

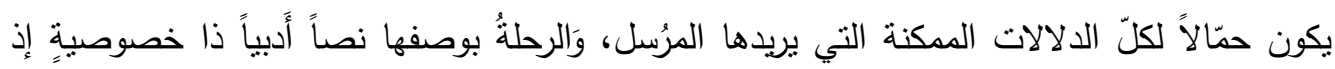

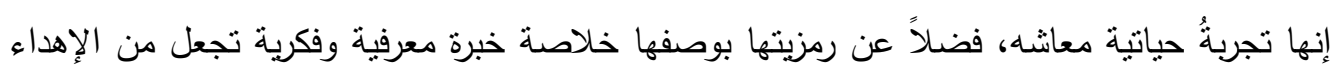
ومغاليقهُ مهماً بقدر العتبات الأخرى كلّها. يهدي (زكي مبارك) رحلته (ذكريات باريس) إلى: 
إلى الأستاذ ((عبد القادر حمزة*)) أُهاي هذا الكتاب"(؟r).

لذا كان الإهداء مُتتاغماً مع طبيعة الرحلة فالمُهدى إليه قد (وَصل الجناح وراش السهم)

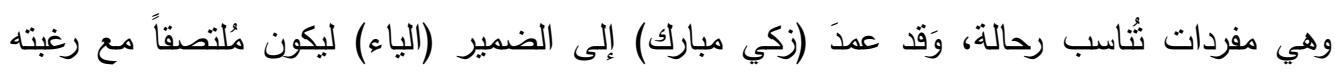

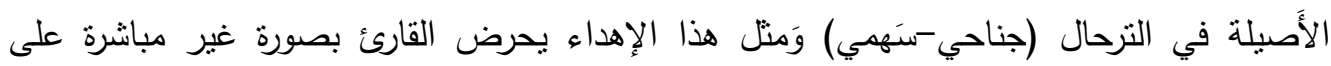

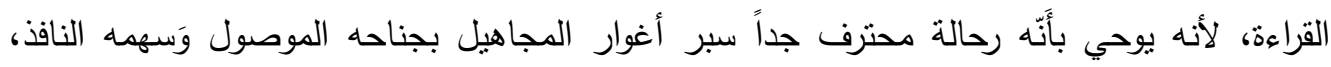

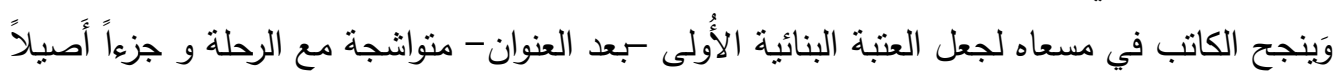

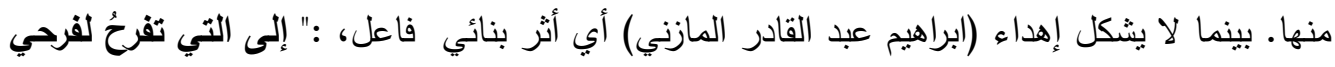

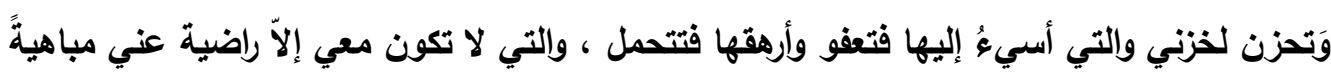

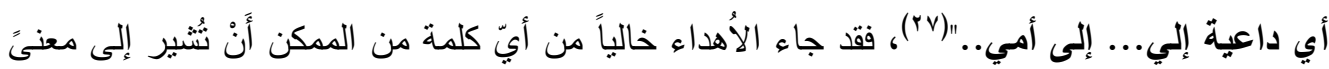

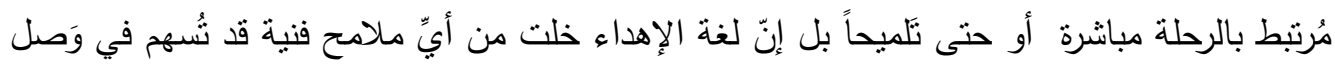

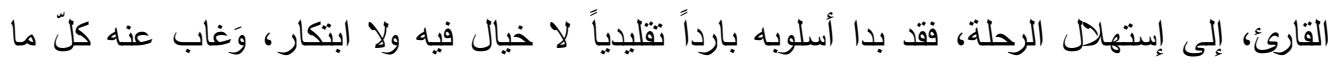

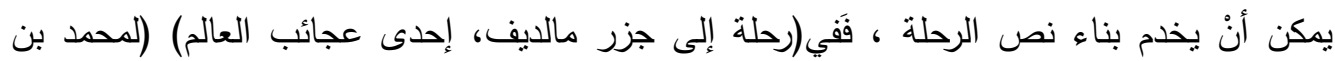

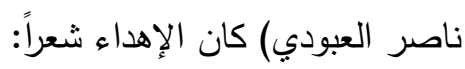
(مَلايف) يا حَلم الزمان الغافي يا درّة الغوّاص فـــــي الأَصدافِ أَنتِ التي اخترت دين محمد وَتـــــركت طوعاً باطل الأسلافِ

\section{مَنح الإله مواطنيكِ طبيعةً}

رقــــــراقة كـــــالسلسبيل الصافي

وخلا من الحرب الضروس سجلَّهُمٍ

فغدوا عديمي المثل في الأنصافِ(†^) 
والإهداء شعراً يحيل إلى محاولة الرّحالة الإيحاء بجمال رحلته القادمة، لأَنَهُ لم يجد نثراً يقدم به فلجأ

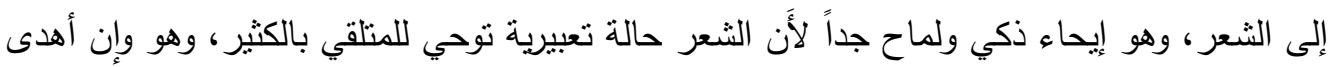
الرحلة إلى (جزر المالديف):

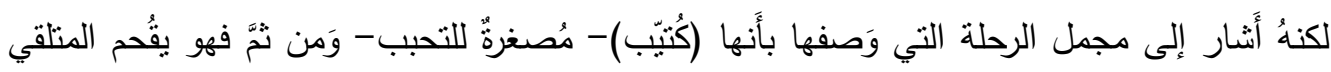

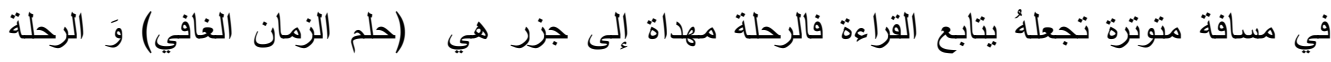

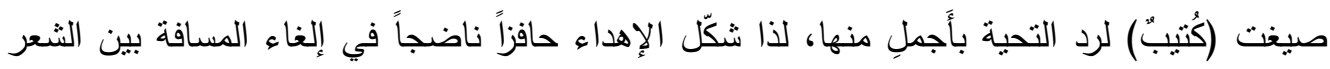
والنثر في ذهن المتلقي لأَنْ الرحلة (أَسطرُ وقوافي).

وييدو إنّ لكلّ رحلةٍ مناخها النفسي فغيابُ الإهداء من منتها دليل على إنها ليست بمكانة الرحلة الممهورة بالإهداء، فالرحالة (محمد بن ناصر العبودي) ترك كوعلى سبيل المثال لا الحصر - رحلاته

الآتية: - الآن

$$
\text { 1-القلم وما أوتي، في جييوتي. }
$$

r-داخل أَسوار الصين، رحلة وحديث عن شؤون المسلمين.

r-بيليز والسلفادور وحديث عن السلمين.

ع-المستفاد من السفر إلى تنشاد.

ه-أَيام في فيتتام.

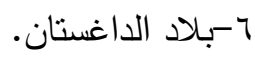

V-بلاد البلطيق، رحلة وحديث عن المسلمين. 
تركها بدون إهداء، لتأتي أَثُبه بالتقارير العلمية الجغرافية المكتوبة بدون رغبة ذاتية بل بدت وكأَنها

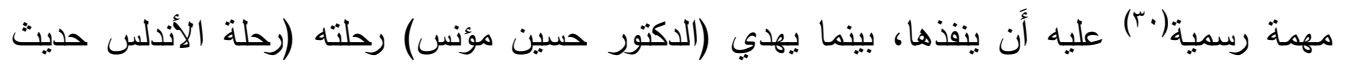

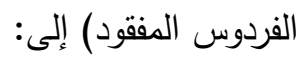

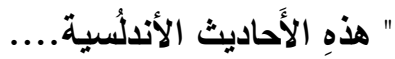 \\ مهاة إلى الصديق الكريم: أَحمد نجيب هاشم** \\ ومهداة إلى كلّ من سيسير بعدنا على ذلك الدرب الطويل"("r).}

ممازجاً بين الإثارة الني جاءت في العنوان الفرعي (حديث الفردوس المفقود) لنكون (الأحاديث) هي

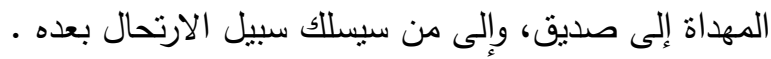

وهو بذلك بلمحُ إلى إنّ هذهِ الأحَاديث لا غنىً عنها لكلّ من يروم زيارة الأَندلس عبر رحلته اللغوية في فردوسها المفقود .

ومن تأمل مجموعة من الاهداءات في الرحلة الأَدبية الحديثة يمكننا أَن نَحدد مجموعة من النقاط حولها ، وهي :

1-إهداءات تتجح في مدّ أواصرها مع متن الرحلة محفزةً القارئ على التواصل والاهتمام بالمنجز الرّحلي.

ץ-إهداءات لا تقدم للرحلة أية إضافة وَتبقى مجرد مقطع لغوي مجتزئ منفصل عن الرحلة. ب-إنّ طبيعة النص في الرحلة مختلفة عن الفنون الإبداعية الأخرى لذا تبدو مهمة الإهداء أَصعب،

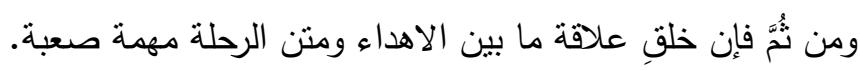

ثالثاً: العبارات الافتتاحية : - n

لحاجة موضوعية وَّبائية يستشعرها الرحالة ويراها ضرورية لاستكمال نصّه يلجأ إلى وَضع

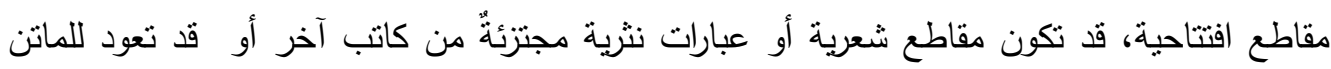




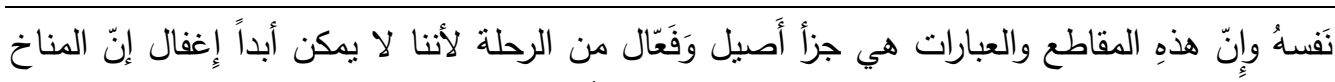

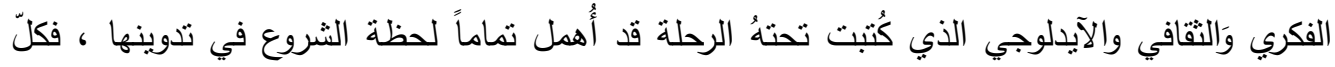

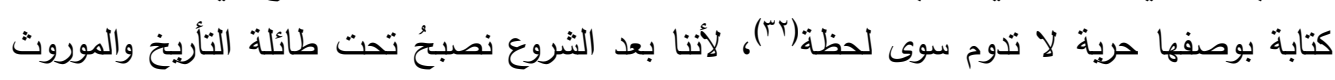

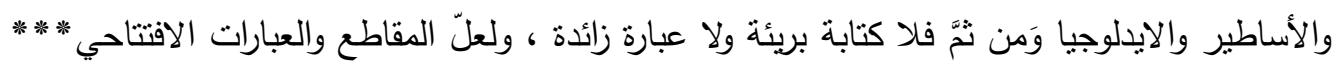

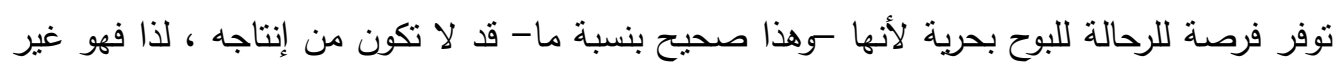

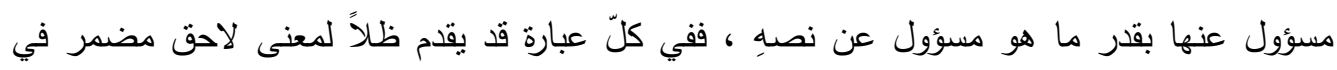

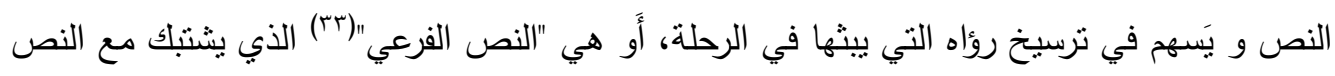

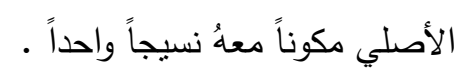

إِّن المتأَمل في الدراسات الني اختصنّت بفحص العتبات النصية يجدها قد أَولت العنوان إهتماماً كبيراً

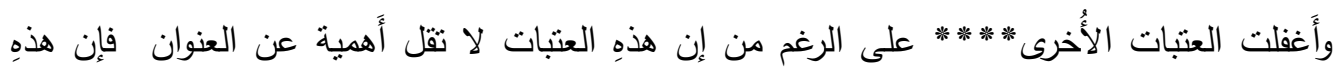

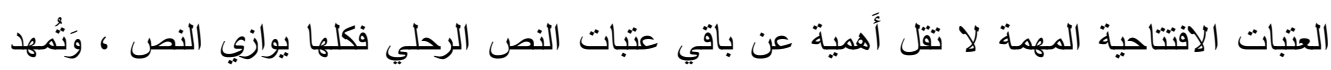

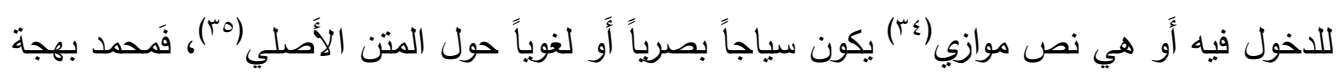
البيطار في رحلته (الرحلة النجدية الحجازية ) يقدم لها بمقدمة يضمنها النقاط التالية :

أولاً : ( مخاطر الرحلة ) فيقول " فسافرنا بمشيئة الله متوكلين عليه ، مسلمين أَمرنا إليه ، ولقينا

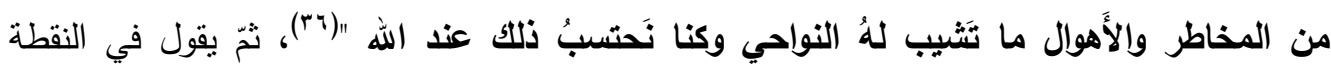

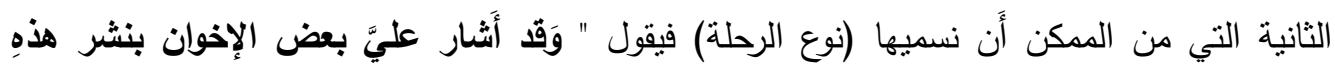

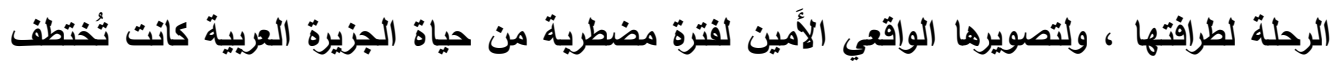

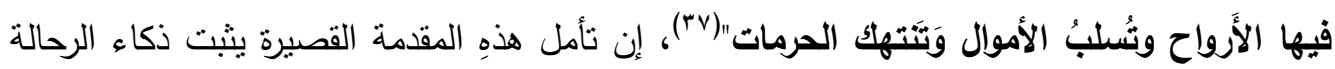

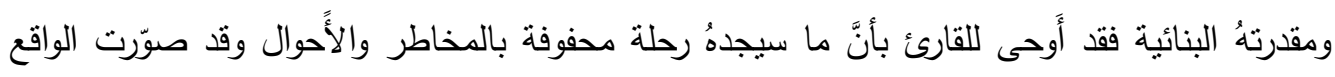

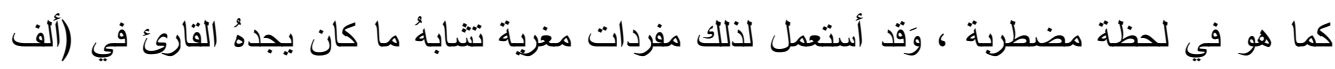

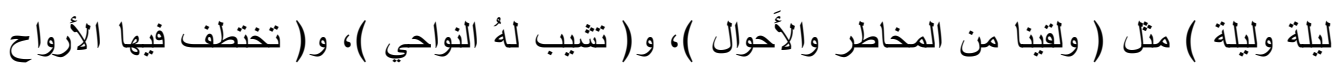

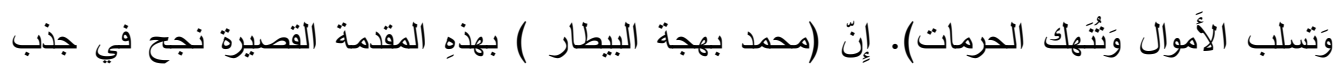
القارئ وأَسره داخل سطور الرحلة .وسواء صدق وَصفه لرحلته أم لا فهو قد أَنجز عَتبة بنائية ناجحة مهدت للاخول في عنباتٍ أخرى . 
ومثلاُ يحاول (شكيب أرسلان) في (مقدمته) أَن يُلَّمَح من رحلته ( الإرتنسامات اللطاف في خاطر الحاج

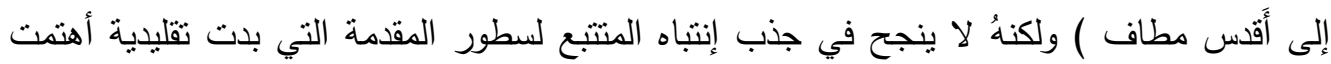

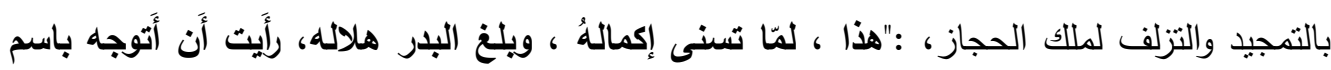

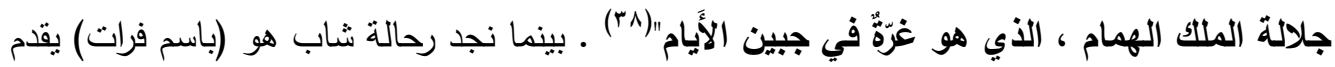

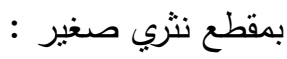

\section{حينما ودَعَثُ الطفولة}

حالماً بالسفر والترحال

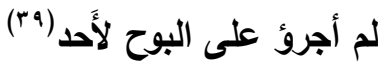

يلمحُ إلى إنّهُ وهو العازم على خوض غمار الرحلة سيودع الطفولة وهو لا يجرؤ على البوح لأَحد لأن

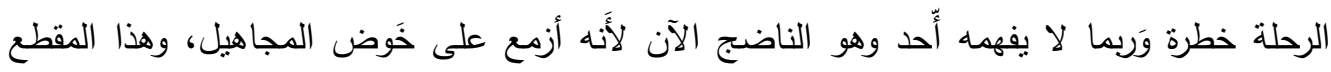

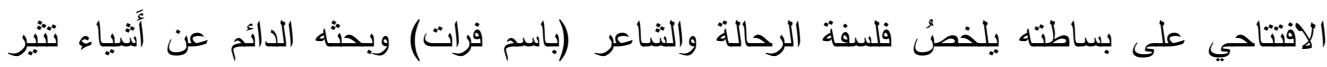

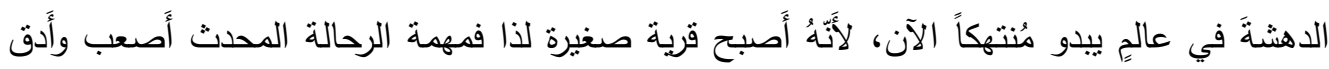

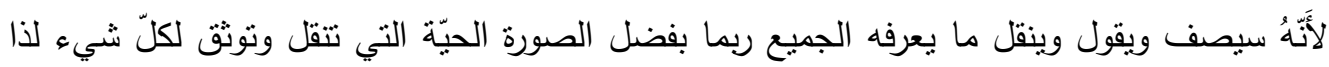

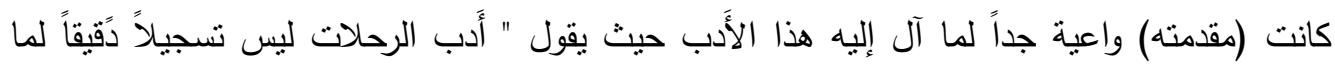

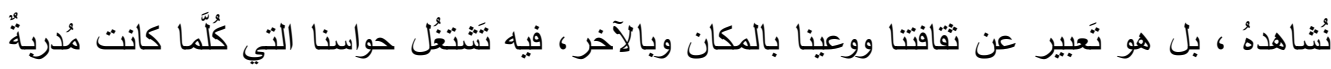

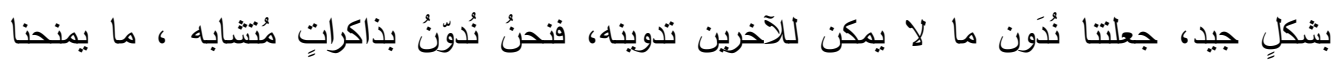

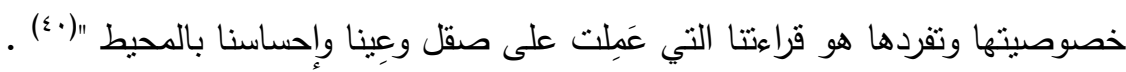

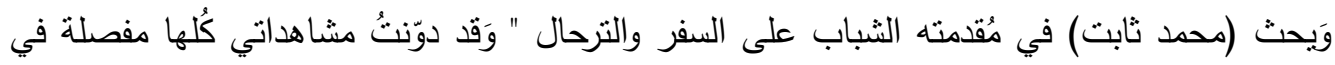

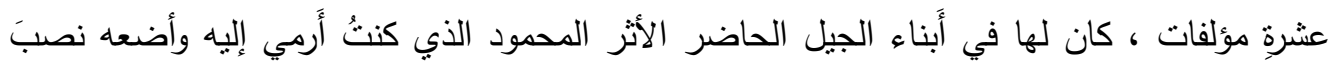

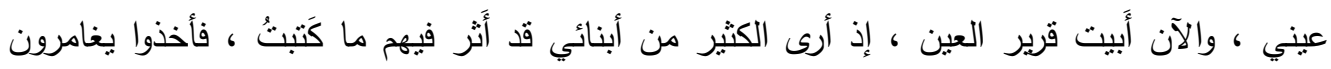

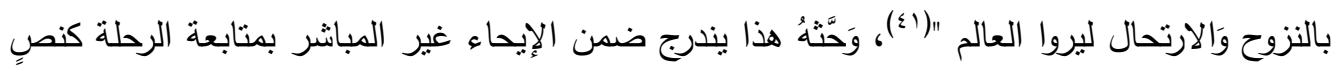

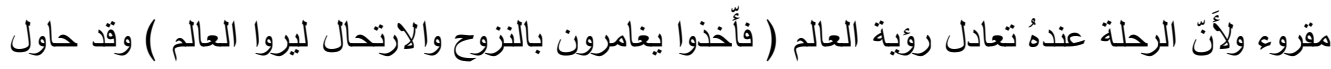

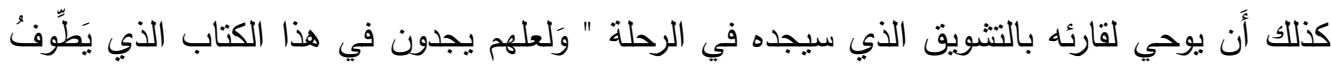

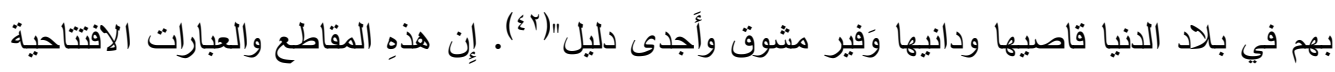


تلائم الرحلة لأنَها نََسم بصفاتٍ تجعلها فنّاً يمكن أَن يُقَمُ لهُ ما يوفر للرحالة فرصة كبيرة للتتويه عن خصائص رحلته أَو دفع القارئ نحوها، وبعد الاطلاع على الكثير من هذهِ العبارات والمقاطع يمكننا القول إِنّ هذهِ المقاطع والعبارات تَندرج تحت نقاطٍ ثلاثة :

أَولاً : مقاطع وَعبارات على هيكل الرحلة لا تقدم لها إضافة بنائية مهمة، وتبدو زائدة وَغير مُنسجمة مع فضاء الرحلة .

ثانياً : مَقاطع وَعبارات تَجَح في مدّ أَواصر بنائية مَع جسد الرحلة وتتواشج مع جزيئاتها مكونة معها

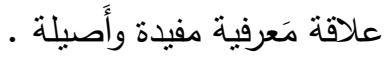

ثالثاً: مقاطع وَعبارات بدت فاعلة بصورة مخالفة ، إذ فَتَلت في تقديم الرحلة وأسههت في تعويم المقطع الافتتاحي وإخراجه من حيز البناء للرحلة .

المصادر والمراجع :

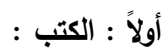

1- أحسن التقاسيم في معرفة الأقاليم ، البشاري المقدي ، تح: محمد مخزوم ، دار أحياء التراث العبي ، بيروت - مो $91 \mathrm{~V}$ ،

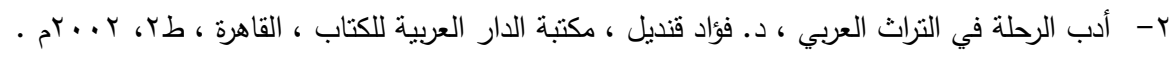

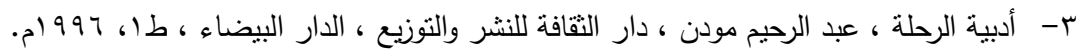

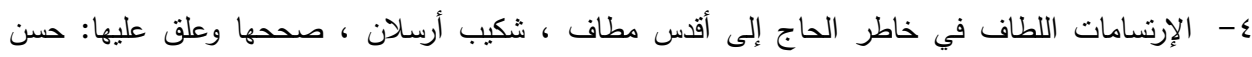

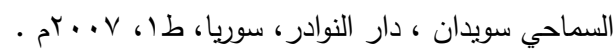

ه- استرداد المعنى ـ دراسة في أدب الحداثة ، عبد العزيز إبراهيم ، دار الثؤون النقافية العامة ، بغداد ، طا ،

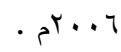

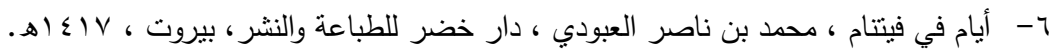

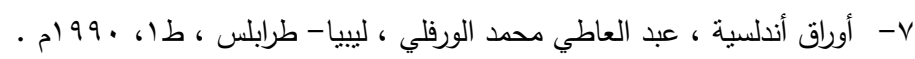

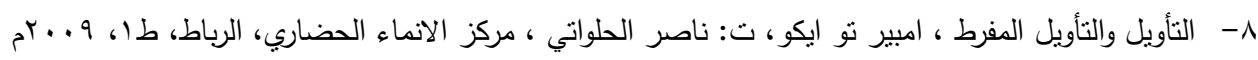

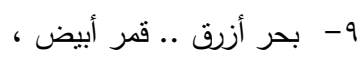

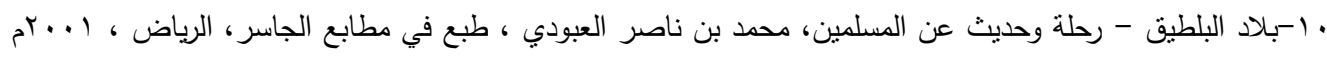




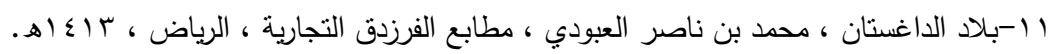

r ا-بيليز والسلفادور وحديث عن المسلمين ، محمد بن ناصر العبودي ، مطبعة العلا ، السعودية، طا، ا .. rم .

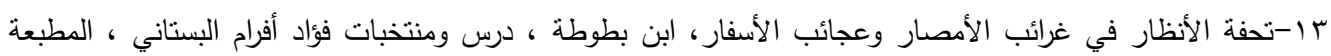

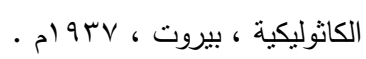

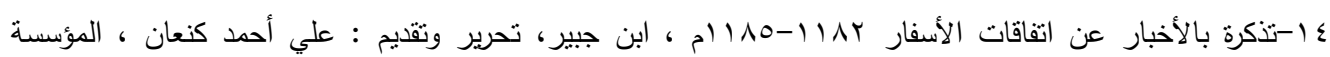

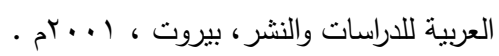

ه ا-ثريّا النص- ددخل لدراسة العنوان القصصي(الموسوعة الصغيرة/ عجوب)، محمود عبد الوهاب، دار الثؤون الثقافية ، بغداد ، 990

ج ا- جماليات التشكيل الروائي- قراءة في الملحمة الروائية ((مدارات الثرق)) لنبيل سليمان ، محمد صابر عبيد بالاشتراك

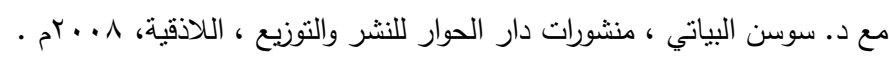

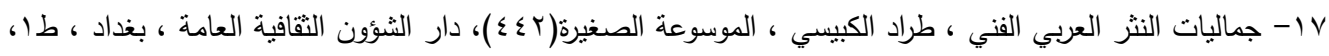
. 9 1- الحلم البوليفاري، رحلة كولومبيا الكبرى ، باسم فرات، الحضارة للنشر ، مصر ، طا، 10 • ب م.

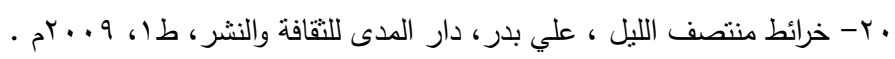

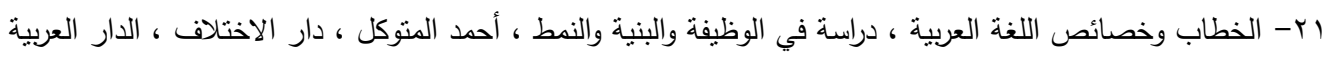

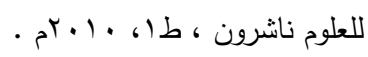
بr-داخل أسوار الصين ، رحلة وحديث في شؤون المسلمين ، محمد بن ناصر العبودي ، مطابع الفرزدق التجارية ،

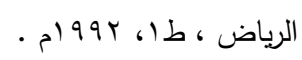

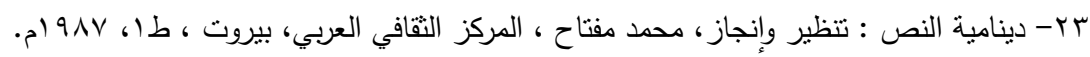

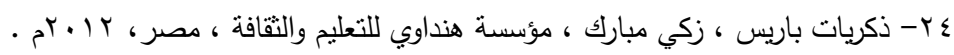

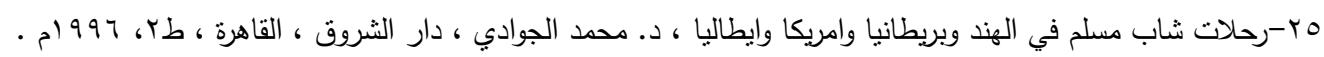

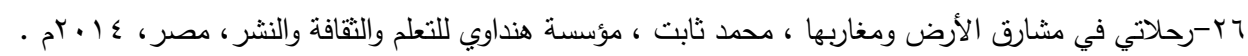

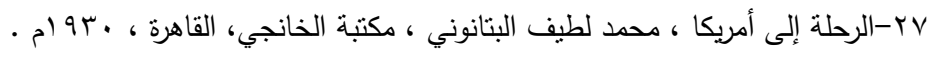

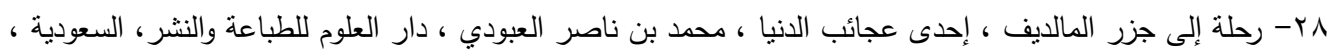
- ط و و-رحلة إلى الحجاز، إبراهيم عبد القادر المازني ، الهيئة المصرية العامة للكتاب ، مطبوعات الجديد، ع( اب)، طץ، . $19 \vee r$ • ب- رحلة إلى الحجاز، إبراهيم عبد القادر المازني ، مؤسسة هنداوي للتعليم والثقافة ، مصر ، د.ت.

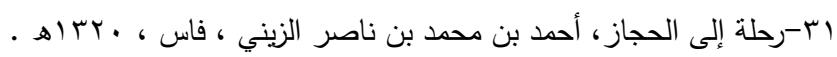

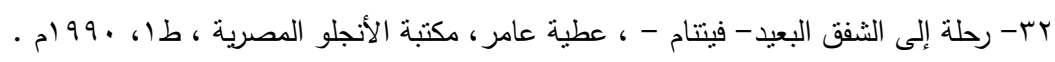

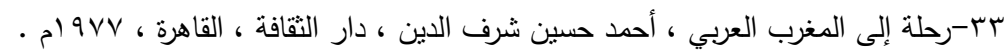




\section{العـــــــد التاسع و والعشرون}

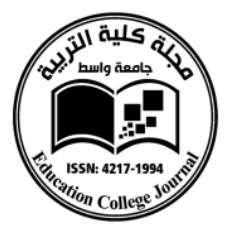

ع ז- رحلة الأندلس ، حديث الفردوس المفقود ، د. حسين مؤنس ، الدار السعودية للنشر والتوزيع، طץ، 910 ام .

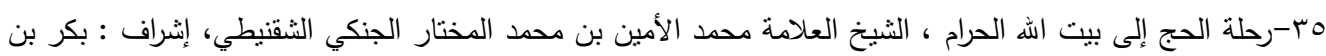

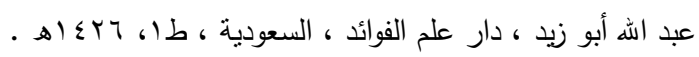

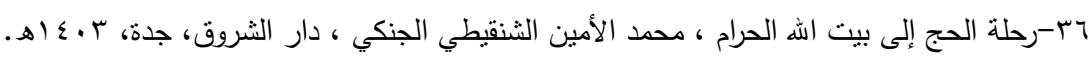

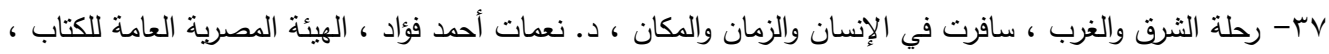

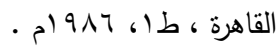

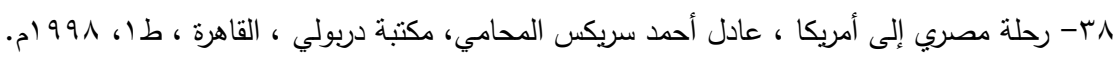

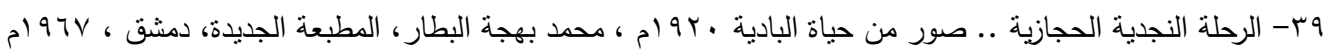

• ع- رحلتي إلى اليمن العربية السعيدة ، أحمد مزيد الرفاعي ، مطبعة محمد علي صبيح ، القاهرة ، 901 ام .

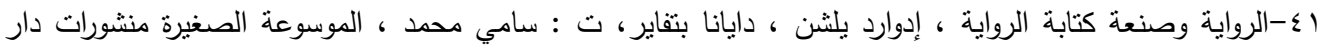

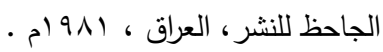

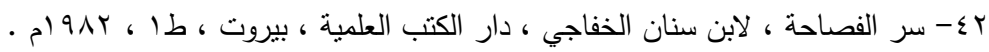

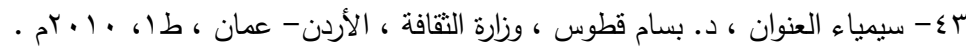

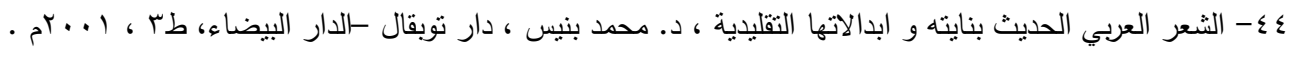

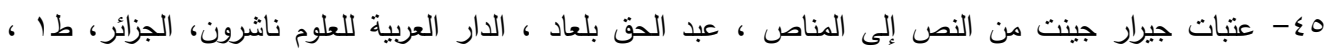
- 1994

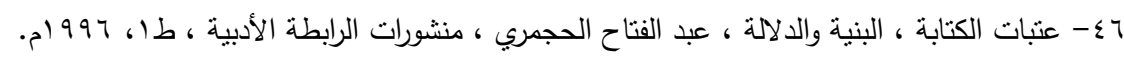

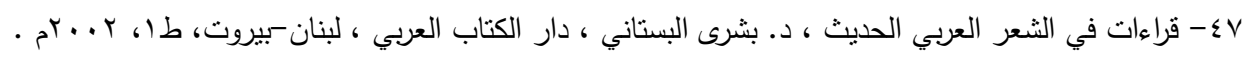

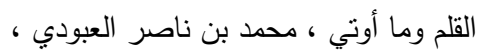

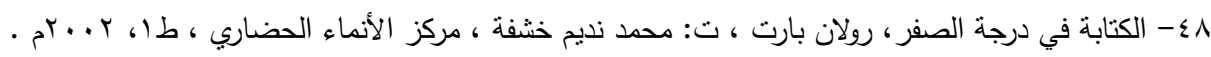

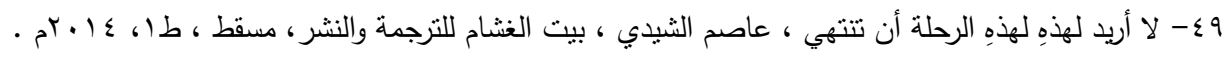

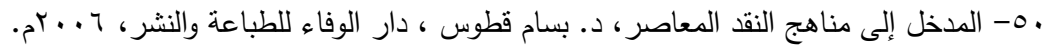

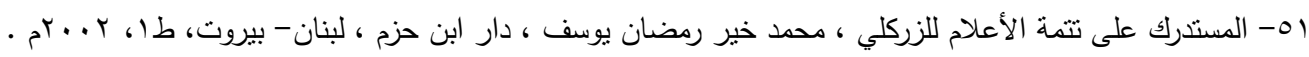

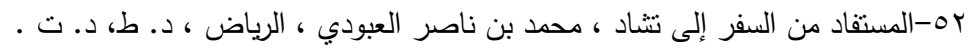

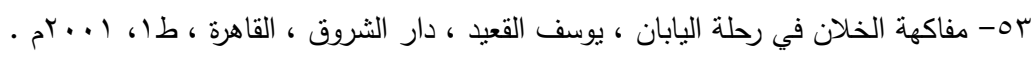

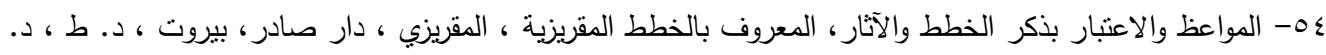

0. الموكوس في بلاد الفلوس ، محمود السعني ، مؤسسة أخبار اليوم ، مصر ، 99 ام .

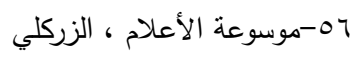

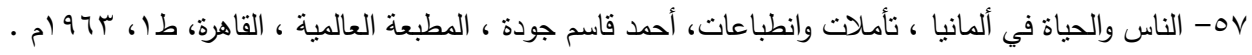


هـ- هوية العلامات في العتبات وبناء التأويل ، د. شعيب حلفي ، دار الثقافة للنشر والتوزيع ، مطبعة النجاح ، المغرب ،

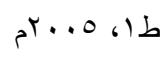

ثانياً : المجلات والدوريات :

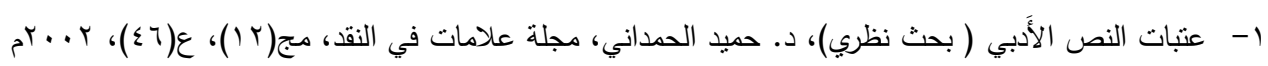
r- العنوان في الثعر العراقي المعاصر، أنماطه وَوَظائفه، أ.م. د. ضياء الثامري، مجلة القادسية للآداب والعلوم

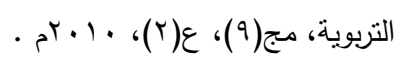

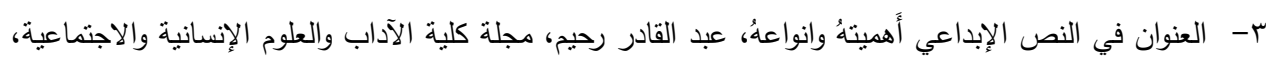

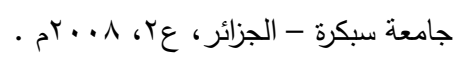

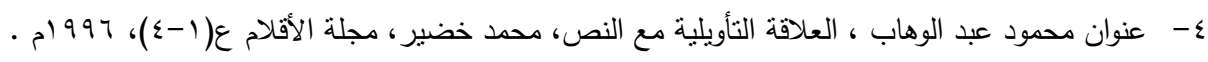

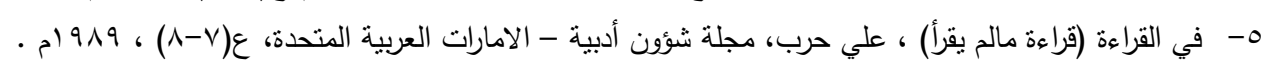

\section{الهوامش :}

(1) ينظر: عنوان محمود عبد الوهاب ، العلاقة التأويلية مع النص، محمد خضير، مجلة الأقلام ع(1-)، 997 ام:

(ץ) ينظر : العنوان في الثُعر العراقي المعاصر ، أنماطه وَوَظائفه، أ.م. د. ضياء الثامري، مجلة القادسية للآداب والعلوم

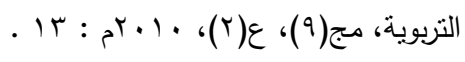

$$
\begin{aligned}
& \text { (ع) ينظر : عتبات النص الأدبي : ^^ . . } \\
& \text { (0) هوية العلامات : 11 } \\
& \text { (T) ينظر : سيماء العنوان : بr . }
\end{aligned}
$$

(V) ينظر: على سبيل المثال لا حصر : تذكرة بالأخبار عن اتفاقات الأسفار لابن جبير، وتحفة الأنظار في غرائب

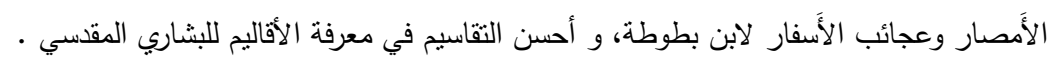




\section{العــــــدد التاسع و والعشرون}

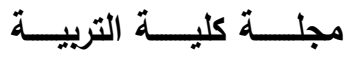

"من الرحلات الحديثة التي لجأت إلى العنوان السجعي : مفاكهة الخلان في رحلة اليابان، يوسف القعيد، ورحلة الموكوس

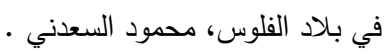

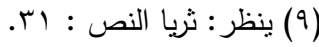

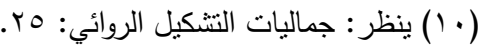

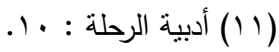

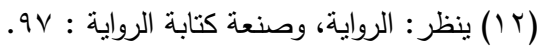

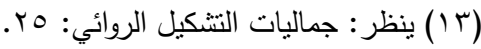

(ع 1) ينظر : عنبات جيرار جينت من النص إلى المناص : 1 م وما بعدها.

: (10) من العنوانات الفنية

-رحلة إلى الثفق البعيد ، عطية عامر ، .99 ام .

-خرائط منتصف الليل ، علي بدر ، 9 + بم •

-بحر أزرق .. قمر أبيض ، حسن البحار ، عـ ا.بم .

-لا أريد لهذه الرحلة أن تنتهي ، عاصم الثيدي ، عـ ا بام .

(7 (1) ينظر : العنوان في النص الإبداعي أَهميتهُ وانواعهُ، عبد القادر رحيم، مجلة كلية الآداب والعلوم الإنسانية

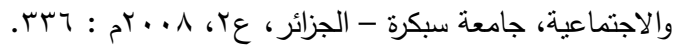

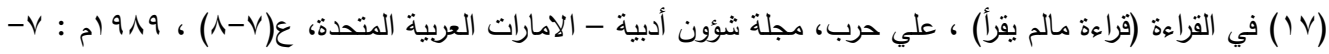

(1) (1) (ماليات النثر العربي-الفني)، الموسوعة الصغيرة : .

(19) ينظر : الخطاب وخصائص اللغة العربية : بآ.

(r·)

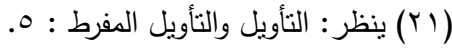

(rr) ينظر : قراءات في الثعر العربي الحديث : ـr. 


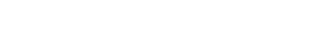

$$
\begin{aligned}
& \text { (r (r) سردية النص الأَدبي : rrا. } \\
& \text { (Y ( أدب الرحلة في التراث العربي : 7. } \\
& \text { (ro) المدخل إلى مناهج النقد المعاصر : . . . . } \\
& \text { (צr) عنبات الكتابة، البنية والدلالة : . r. }
\end{aligned}
$$

(YV) ذكريات باريس : 9 ـ ينظر : إهداء عادل أحمد سريكس في رحلته، رحلة مصري إلى امريكا: ه .

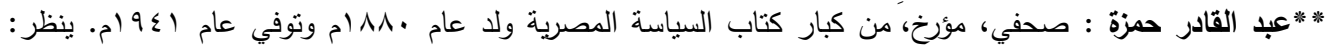

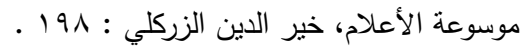

(Y^) رحلة إلى الحجاز: 0. ينظر : إهداء رحلة : أوراق أندلسية، عبد العاطي محمد الورفلي: هـ ، وكذللك إهداء الدكتور

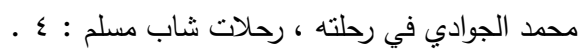

$$
\begin{aligned}
& \text { (ץq) رحلة إلى جزر مالديف : r. } \\
& \text { (r) }
\end{aligned}
$$

(آب) ينظر : رحلة (أَيام في فيتتام) ، وغيرها من رحلاته.

**\%"حمد نجيب الثيخ : تربوي ودبلوماسي، وكاتب ومترجم مصري، له العديد من المترجمات منها : القياصرة القادمون،

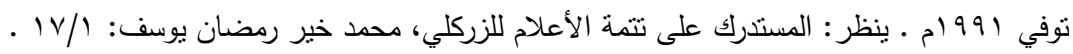

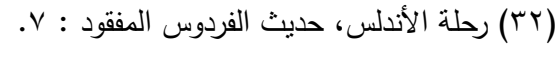

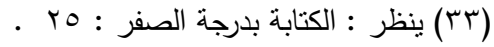

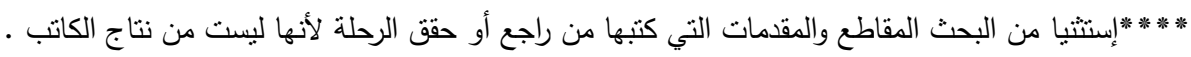

$$
\begin{aligned}
& \text { (؟ استرداد المعنى ، دراسة في أَدب الحداثة : } 107 \text { ـ } \\
& \text { : من الدراسات التي نتاولت العنوان ****** }
\end{aligned}
$$

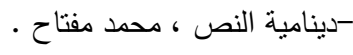

$$
\begin{aligned}
& \text { سيماء العنوان ، بسام قطوس. }
\end{aligned}
$$

- العنوان وسيميوطقبا الاتصال الأَبي ، محمد فكري الجزار • 


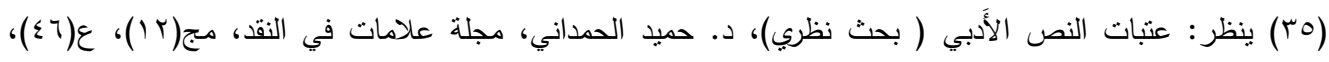

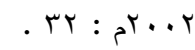

( (؟r) ينظر : الشعر العربي الحديث ( بنايته وابدالاتها) التقليدية : 1 ـ1 .

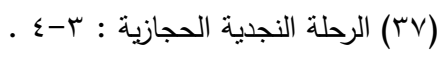

.

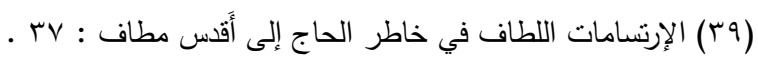

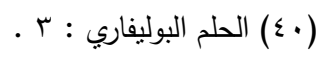

. $1:$ :

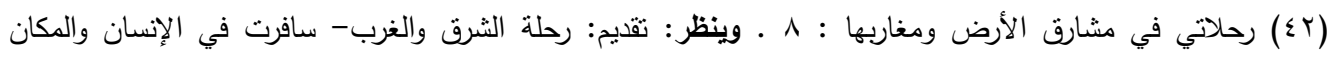

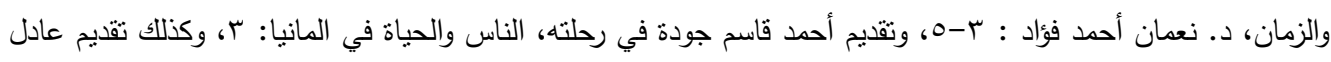

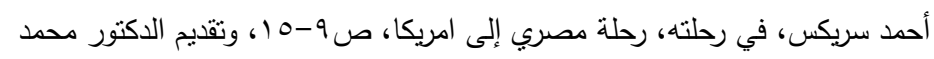

الجوادي في رحلته، رحلات شاب مسلم، صه-1، حيث كتب مقدمتين لطبعتي الرحلة .

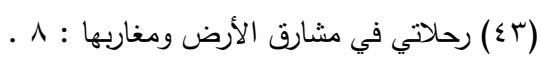

